\title{
Diversity and biochemical features of culturable fungi from the coastal waters of Southern China
}

\author{
Li Li ${ }^{1,2}$, Purnima Singh ${ }^{1}$, Ying Liu', Shenquan Pan ${ }^{2}$ and Guangyi Wang ${ }^{1,3,4^{*}}$
}

\begin{abstract}
Fungi play a major role in various biogeochemical cycles of terrestrial and marine ecosystems. However, fungi in marine environments remain to be one of the most under-studied microbial groups. This study investigates the diversity of planktonic fungi from the coastal habitat off Pearl River Delta (China) using culture-dependent approach. A total of 22 fungi and 9 yeast isolates were recovered from 30 seawater and 2 sediment samples. Microscopic and ITS rRNA gene sequence analyses revealed that most of the fungi belonged to the phylum Ascomycota and Basidiomycota with a very small percentage (3\%) of the subphylum Mucoromycotina of the Phylum Zygomycota. Most of these fungal isolates exhibited considerable production of extracellular enzymes, cellulase, lipase and laccase. Fungal isolates of two genera Mucor and Aspergillus sp. demonstrated pelletization capability over a wide range of $\mathrm{pH}$, suggesting them as potential agents towards algae harvesting and wastewater treatment.
\end{abstract}

Keywords: Marine-derived fungi; Diversity; Hydrolytic enzymes; Pelleterization

\section{Introduction}

Coastal marine habitats have been characterized as the most variable, highly diverse and rich in primary production (Jickells 1998; Danovaro and Pusceddu 2007). The primary production in coastal habitats sometimes reaches very high levels resulting into availability of a great fraction of organic matter for consumers as detritus even after consumption of herbivores (Newell 1982). Different types of microbes in coastal waters degrade a large proportion of this detritus actively (Manini et al. 2003; Pusceddu et al. 2003). Among these microbes, heterotrophic bacteria and archaea have been described for their degradation abilities towards such detritus to a greater extent (Moran and Miller 2007; Mou et al. 2008). In spite of being a significant component of coastal waters, the diversity and ecology of heterotrophic eukaryotes however has not been received much attention (Giovannoni and Stingl 2005; Hallam et al. 2006; Fenchel 2008; Strom 2008).

Among eukaryotes, fungi have been reported to exhibit as individual filaments or aggregates in coastal waters

\footnotetext{
* Correspondence: gywang@tju.edu.cn

${ }^{1}$ School of Environment and Energy, Peking University Shenzhen Graduate School, Shenzhen, 518055, China

${ }^{3}$ Tianjin University Center for Marine Environmental Ecology, School of Environmental Science and Engineering, Tianjin University, Tianjin 300072, China

Full list of author information is available at the end of the article
}

(Gutiérrez et al. 2010). However, in comparison with terrestrial environments, fungi in the world's oceans remain largely unknown (Gao et al. 2010). Despite of a few reports on diversity of fungi from the oceans, the diversity and ecology of their planktonic forms (mycoplankton) have barely been explored (Richards et al. 2012). Mycoplankton include free-living filamentous fungi, yeasts, fungal-like protists, and those associated with planktonic particles or phytoplankton (Wang and Johnson 2009; Gao et al. 2010).

Fungi are a key component of the biosphere, fulfilling a wide range of biogeochemical and ecological functions in natural environments (Christensen 1989; Pang and Mitchell 2005). They are best known as decomposers of organic matter and play major role in nutrient regeneration in the detrital ecosystems. The filamentous mycelia may greatly enhance the efficient mineralization of particulate organic matter (Tisdall and Oades 1982; Damare and Raghukumar 2008) and thus benefit the growth of planktonic microbial communities (Kiørboe and Jackson 2001; Gutiérrez et al. 2010). The biomass of planktonic fungi has been reported to be comparable with prokaryotes including both Bacteria and Archaea (Gutiérrez et al. 2011).

Fungi occupy distinct ecological niches from that of bacterioplankton in detritus ecosystems with the ability to utilize large lignocellulose-predominated substrates 
with high C: N ratio (Newell 1994; Raghukumar 2004). They possess the ability to penetrate relatively persistent particulate detritus much more efficiently than bacterioplankton (Raghukumar 2004). The endophytic fungi have been demonstrated to reside within marine plants intra or intercellularly, and produce a variety of bioactive and chemically active metabolites (Kaul et al. 2013). The bioactive metabolites produced by endophytic fungi originate from different biosynthetic pathways and belong to different groups of terpenoids, steroids, quinones, phenols and coumarins (Kaul et al. 2013). Therefore, the endophytes represent a potential chemical reservoir for anticancer, antioxidant, antiviral and insecticidal compounds for pharmaceutical and agrochemical industries. Two new benzopyranones, diaportheone $\mathrm{A}$ and $\mathrm{B}$, were obtained via bioassay-guided isolation of the secondary metabolites from the endophytic fungus Diaporthe sp. P133 isolated from Pandanus amaryllifolius leaves (Bungihan et al. 2011). These benzopyranones have been successfully used as antimicrobial compounds towards several microorganisms. One of the fungal isolate belonging to Aureobasidium pullulans has been exhibited as a reservoir of biotechnologically active products in previous reports (Chi et al. 2009).

Considering the crucial role of planktonic fungi in versatile oceanic biogeochemical cycles, their diversity needs to be addressed from different ecosystems. The coastal habitats of Pearl River Delta, China have been highly productive ecosystems of China, being the major source for fishing industries. However, recently there has been an increased pollution level detected in these ecosystems which may further enhance detritus levels available for degradation. Therefore, the mycoplankton diversity studies from these still unexplored habitats may provide greater insight on potential fungal isolates playing significant role in ecological cycles of Pearl River Delta. This study is the first report on diversity of planktonic fungi based on culture-dependent approach from the coastal habitats of Pearl River Delta.. Potential fungal isolates were further investigated for the production of different extracellular enzymes such as laccase, lipase and cellulase in order to understand their active role in ecological cycles of coastal ecosystems.

\section{Materials and methods}

\section{Sample collection and isolation of fungi}

Seawater and sediment samples were collected from coastal marine habitats of Pearl River Delta region of China during March, 2012 (Table 1). These samples were carried in sterile, screw capped plastic bottles and bags immediately back to the laboratory for isolation. The isolation of fungi from the seawater samples was done within one hour of collection using the membrane filtration technique. Briefly, $15 \mathrm{ml}$ triplicate water samples were filtered through sterile $0.45 \mu \mathrm{m}$ cellulose ester membranes (Millipore, USA). These membranes were then placed on solid media plates, Malt Extract Agar (MEA), Sabouraud Dextrose Agar (SDA), Potato Dextrose Agar (PDA), Czapek Dox Agar (CDA) and Corn Meal Agar (CMA), supplemented with antibiotics $(0.075 \%$ streptomycin and $0.05 \%$ ampicillin) to suppress bacterial growth. Sediment samples $(0.1 \mathrm{~g})$ were suspended in $10 \mathrm{ml}$ sterile seawater and $100 \mu \mathrm{l}$ of the resulting suspension was plated directly on the above media plates containing antibiotics. The plates were incubated at room temperature $\left(28^{\circ} \mathrm{C}\right)$ and examined daily for the growth of fungi. Fungal colonies that developed were subcultured onto fresh MEA plate for pure, single colony isolation and identification. The identification of filamentous fungi was done by macroscopic and microscopic morphology (Additional file 1: Figure S1). Three promising strains (Rhodosporidium sp. PKU Y5, Rhodotorula sp. PKU Y7 and Cladosporium sp. PKU F16) have been deposited in China General Microbiological Culture Collection Center (CGMCC No. 2.5198, CGMCC No. 2.5199 and CGMCC No.3.17121).

\section{Isolation and sequencing of ITS rRNA gene from the fungal isolates}

All the isolated fungi were grown in MEB for 4-5 days for DNA isolation. Yeasts were grown in YPD (yeast extract peptone and dextrose) medium and shaken at $170 \mathrm{rpm}$ for 3-4 days. Mycelia and cells were harvested, lyophilized and crushed in a mortar and pestle to fine powder. Isolation of DNA was carried out using the Ezup Soil DNA extraction kit (Sangon Biotech, China), following the manufacturer's guideline. The small subunit ITS rRNA gene was amplified by polymerase chain reaction (PCR) in the DNA T100 Thermal cycler (Bio-Rad, USA) using the ITS rRNA gene specific primers ITS1 (5'-TCCGTAGGTGAACCTGCGG3') and ITS4 (5'-TCCTCCGCTTATTGATATGC-3') (White et al. 1990). One microliter of DNA ( $25 \mathrm{ng}$ ) was added to $50 \mu \mathrm{l}$ reaction volume containing $25 \mu \mathrm{l}$ of Taq PCR mix (Generay, China) , $23 \mu \mathrm{ldd}$ water and 5 pmoles of each primer. The PCR program was run for initial denaturation step at $95^{\circ} \mathrm{C}$ for $3 \mathrm{~min}$, followed by 35 cycles of $1 \mathrm{~min}$ at $94^{\circ} \mathrm{C}, 0.5 \mathrm{~min}$ at $50^{\circ} \mathrm{C}$ and $1 \mathrm{~min}$ at $72^{\circ} \mathrm{C}$, and a final extension at $72^{\circ} \mathrm{C}$ for $5 \mathrm{~min}$. The PCR products were purified using Gel DNA extraction kit (NewTopBio, China). Amplified products were transformed into Escherichia coli DH5 $\alpha$ cells (Invitrogen, Carlsbad, CA, USA), following the manufacturer's instructions. Transformants were grown overnight at $37^{\circ} \mathrm{C}$ in LuriaBertani broth containing $100 \mathrm{mg}$ of ampicillin. The presence of insert was confirmed by PCR with M13 forward and reverse primers. One $\mathrm{ml}$ of the broth containing the clone was added to $25 \mathrm{ml}$ of PCR reaction mixture. PCR protocol included an initial hot start incubation $\left(5 \mathrm{~min}\right.$ at $94^{\circ} \mathrm{C}$ ) followed by 34 cycles of 
Table 1 Details regarding colony forming units (CFUs) of fungal colonies on the media plates

\begin{tabular}{|c|c|c|c|c|c|c|c|c|c|c|}
\hline Sampling date & Location & Lat $\left({ }^{\circ} \mathrm{N}\right)$ & Long $\left({ }^{\circ} \mathrm{E}\right)$ & Habitat & $\begin{array}{l}\text { Depth } \\
(\mathrm{m})\end{array}$ & $\begin{array}{l}\text { Temperature } \\
\left({ }^{\circ} \mathrm{C}\right)\end{array}$ & $\begin{array}{l}\text { Salinity } \\
\text { (ppt) }\end{array}$ & Media & No. of colonies & CFU/L \\
\hline \multirow[t]{8}{*}{ 2012-03-05 } & Shenzhen Bay & $22^{\circ} 31^{\prime} 19.776^{\prime \prime}$ & $113^{\circ} 57^{\prime} 4.284^{\prime \prime}$ & Seawater & 0 & 16.25 & 31.02 & MEA & 3 & 120 \\
\hline & & $22^{\circ} 31^{\prime} 19.776^{\prime \prime}$ & $113^{\circ} 57^{\prime} 4.284^{\prime \prime}$ & Seawater & 0 & 16.25 & 31.02 & SDA & 2 & 80 \\
\hline & & $22^{\circ} 31^{\prime} 19.776^{\prime \prime}$ & $113^{\circ} 57^{\prime} 4.284^{\prime \prime}$ & Sediment & 0 & 16.25 & 31.02 & MEA & 12 & 480 \\
\hline & & $22^{\circ} 31^{\prime} 19.776^{\prime \prime}$ & $113^{\circ} 57^{\prime} 4.284^{\prime \prime}$ & Sediment & 0 & 16.25 & 31.02 & SDA & 55 & 2200 \\
\hline & Daya Bay & $22^{\circ} 35^{\prime} 34.224^{\prime \prime}$ & $114^{\circ} 30^{\prime} 28.800^{\prime \prime}$ & Seawater & 0 & 16.25 & 31.02 & MEA & 4 & 160 \\
\hline & & $22^{\circ} 35^{\prime} 34.224^{\prime \prime}$ & $114^{\circ} 30^{\prime} 28.800^{\prime \prime}$ & Seawater & 0 & 16.25 & 31.02 & SDA & 5 & 200 \\
\hline & & $22^{\circ} 35^{\prime} 34.224^{\prime \prime}$ & $114^{\circ} 30^{\prime} 28.800^{\prime \prime}$ & Sediment & 0 & 16.25 & 31.02 & MEA & 6 & 240 \\
\hline & & $22^{\circ} 35^{\prime} 34.224^{\prime \prime}$ & $114^{\circ} 30^{\prime} 28.800^{\prime \prime}$ & Sediment & 0 & 16.25 & 31.02 & SDA & 8 & 320 \\
\hline \multirow[t]{28}{*}{ 2012-03-21 } & Mirs Bay & $22^{\circ} 29^{\prime} 44.02^{\prime \prime}$ & $114^{\circ} 27^{\prime} 34.38^{\prime \prime}$ & Seawater & 0 & 17.37 & 31.37 & MEA & 1 & 40 \\
\hline & & $22^{\circ} 29^{\prime} 44.02^{\prime \prime}$ & $114^{\circ} 27^{\prime} 34.38^{\prime \prime}$ & Seawater & 0 & 17.37 & 31.37 & SDA & 3 & 120 \\
\hline & & $22^{\circ} 29^{\prime} 44.02^{\prime \prime}$ & $114^{\circ} 27^{\prime} 34.38^{\prime \prime}$ & Seawater & 5 & 17.37 & 31.37 & MEA & 2 & 80 \\
\hline & & $22^{\circ} 29^{\prime} 44.02^{\prime \prime}$ & $114^{\circ} 27^{\prime} 34.38^{\prime \prime}$ & Seawater & 5 & 17.37 & 31.37 & SDA & 4 & 160 \\
\hline & & $22^{\circ} 29^{\prime} 44.02^{\prime \prime}$ & $114^{\circ} 27^{\prime} 34.38^{\prime \prime}$ & Seawater & 10 & 17.37 & 31.37 & MEA & 3 & 120 \\
\hline & & $22^{\circ} 29^{\prime} 44.02^{\prime \prime}$ & $114^{\circ} 27^{\prime} 34.38^{\prime \prime}$ & Seawater & 10 & 17.37 & 31.37 & SDA & 5 & 200 \\
\hline & Mirs Bay & $22^{\circ} 31^{\prime} 33.14^{\prime \prime}$ & $114^{\circ} 27^{\prime} 51.59^{\prime \prime}$ & Seawater & 0 & 17.74 & 31.37 & MEA & 3 & 120 \\
\hline & & $22^{\circ} 31^{\prime} 33.14^{\prime \prime}$ & $114^{\circ} 27^{\prime} 51.59^{\prime \prime}$ & Seawater & 0 & 17.74 & 31.37 & SDA & 2 & 80 \\
\hline & & $22^{\circ} 31^{\prime} 33.14^{\prime \prime}$ & $114^{\circ} 27^{\prime} 51.59^{\prime \prime}$ & Seawater & 5 & 17.74 & 31.37 & MEA & 4 & 160 \\
\hline & & $22^{\circ} 31^{\prime} 33.14^{\prime \prime}$ & $114^{\circ} 27^{\prime} 51.59^{\prime \prime}$ & Seawater & 5 & 17.74 & 31.37 & SDA & 13 & 520 \\
\hline & & $22^{\circ} 31^{\prime} 33.14^{\prime \prime}$ & $114^{\circ} 27^{\prime} 51.59^{\prime \prime}$ & Seawater & 10 & 17.74 & 31.37 & MEA & 3 & 120 \\
\hline & & $22^{\circ} 31^{\prime} 33.14^{\prime \prime}$ & $114^{\circ} 27^{\prime} 51.59^{\prime \prime}$ & Seawater & 10 & 17.74 & 31.37 & SDA & 10 & 400 \\
\hline & Mirs Bay & $22^{\circ} 31^{\prime} 32.02^{\prime \prime}$ & $114^{\circ} 28^{\prime} 26^{\prime \prime}$ & Seawater & 0 & 17.69 & 31.38 & MEA & 2 & 80 \\
\hline & & $22^{\circ} 31^{\prime} 32.02^{\prime \prime}$ & $114^{\circ} 28^{\prime} 26^{\prime \prime}$ & Seawater & 0 & 17.69 & 31.38 & SDA & 8 & 320 \\
\hline & & $22^{\circ} 31^{\prime} 32.02^{\prime \prime}$ & $114^{\circ} 28^{\prime} 26^{\prime \prime}$ & Seawater & 5 & 17.69 & 31.38 & MEA & 5 & 200 \\
\hline & & $22^{\circ} 31^{\prime} 32.02^{\prime \prime}$ & $114^{\circ} 28^{\prime} 26^{\prime \prime}$ & Seawater & 5 & 17.69 & 31.38 & SDA & 7 & 280 \\
\hline & & $22^{\circ} 31^{\prime} 32.02^{\prime \prime}$ & $114^{\circ} 28^{\prime} 26^{\prime \prime}$ & Seawater & 10 & 17.69 & 31.38 & MEA & 5 & 200 \\
\hline & & $22^{\circ} 31^{\prime} 32.02^{\prime \prime}$ & $114^{\circ} 28^{\prime} 26^{\prime \prime}$ & Seawater & 10 & 17.69 & 31.38 & SDA & 17 & 680 \\
\hline & Daya Bay & $22^{\circ} 34^{\prime} 19.99^{\prime \prime}$ & $114^{\circ} 31^{\prime} 30^{\prime \prime}$ & Seawater & 0 & 19.24 & 31.00 & MEA & 2 & 80 \\
\hline & & $22^{\circ} 34^{\prime} 19.99^{\prime \prime}$ & $114^{\circ} 31^{\prime} 30^{\prime \prime}$ & Seawater & 0 & 19.24 & 31.00 & SDA & 3 & 120 \\
\hline & & $22^{\circ} 34^{\prime} 19.99^{\prime \prime}$ & $114^{\circ} 31^{\prime} 30^{\prime \prime}$ & Seawater & 5 & 19.24 & 31.00 & MEA & 2 & 80 \\
\hline & & $22^{\circ} 34^{\prime} 19.99^{\prime \prime}$ & $114^{\circ} 31^{\prime} 30^{\prime \prime}$ & Seawater & 5 & 19.24 & 31.00 & SDA & 7 & 280 \\
\hline & & $22^{\circ} 34^{\prime} 19.99^{\prime \prime}$ & $114^{\circ} 31^{\prime} 30^{\prime \prime}$ & Seawater & 10 & 19.24 & 31.00 & MEA & 3 & 120 \\
\hline & & $22^{\circ} 34^{\prime} 19.99^{\prime \prime}$ & $114^{\circ} 31^{\prime} 30^{\prime \prime}$ & Seawater & 10 & 19.24 & 31.00 & SDA & 12 & 480 \\
\hline & Daya Bay & $22^{\circ} 34^{\prime} 34.37^{\prime \prime}$ & $114^{\circ} 30^{\prime} 30.46^{\prime \prime}$ & Seawater & 0 & 19.69 & 30.86 & MEA & 3 & 120 \\
\hline & & $22^{\circ} 34^{\prime} 34.37^{\prime \prime}$ & $114^{\circ} 30^{\prime} 30.46^{\prime \prime}$ & Seawater & 0 & 19.69 & 30.86 & SDA & 9 & 360 \\
\hline & & $22^{\circ} 34^{\prime} 34.37^{\prime \prime}$ & $114^{\circ} 30^{\prime} 30.46^{\prime \prime}$ & Seawater & 10 & 19.69 & 30.86 & MEA & 10 & 400 \\
\hline & & $22^{\circ} 34^{\prime} 34.37^{\prime \prime}$ & $114^{\circ} 30^{\prime} 30.46^{\prime \prime}$ & Seawater & 10 & 19.69 & 30.86 & SDA & 8 & 320 \\
\hline
\end{tabular}

denaturation at $94^{\circ} \mathrm{C}$ for $30 \mathrm{~s}$, annealing at $55^{\circ} \mathrm{C}$ for $30 \mathrm{~s}$, and extension at $72^{\circ} \mathrm{C}$ for $1 \mathrm{~min}$ followed by a final extension at $72^{\circ} \mathrm{C}$ for $5 \mathrm{~min}$. Clones containing positive insert were further processed for plasmid isolation and purification using Millipore plasmid preparation kit (Millipore, USA). Clones containing positive insert were sent to BGI (Shenzhen, China) for sequencing analysis using M13 primers.

\section{Phylogenetic analyses}

Forward and reverse sequences were edited and assembled using Chromas Pro version 1.34 (Technelysium Pty Ltd, Tewantia, Queensland, Australia). The final sequences were compared to the nucleotide sequences of reference organisms available in the GenBank database using Blastn (Altschul et al. 1990). The ITS1-5.8S-ITS4 gene sequences obtained for the organisms were aligned with their closest 
match using the program, ClustalW (Thompson et al. 1994). Gaps and ambiguously aligned sequences were removed manually from further analyses. Phylogenetic analyses were carried out using distance setting (Maximum parsimony) in MEGA 4 software (Tamura et al. 2007) with 1,000 bootstrap replicates. The resulting ITS1-5.8S-ITS4 gene sequences were submitted to GenBank under the accession number of KC113282-KC113312.

\section{Qualitative assay for extracellular enzymes}

The enzymatic activity of all the fungal isolates was analyzed in this study. The strains were screened initially using qualitative plate assay for three different enzymes (laccase, cellulase and lipase) by streaking them on the media plates, supplemented with specific substrates. Laccase activity was detected using MEA plates amended with ABTS (2, 2'-azino-bis-3-ethylbenzothiazoline-6-sulfonic acid) (Srinivasan et al. 1995). The fungal isolates were grown on these media plates at room temperature for 4 days. Green color produced around the fungal colonies on media plates indicated laccase activity.

Cellulase (CMCase) activity was detected using carboxymethylcellulose (CMC)-MEA plates (Carder et al. 1986). The CMC-MEA plates comprised $0.5 \%$

Table 2 Phylogenetic affiliations of culturable fungi based on of ITS rDNA gene sequences

\begin{tabular}{|c|c|c|c|c|c|c|}
\hline \multirow{2}{*}{$\begin{array}{l}\text { Isolate } \\
\text { ID }\end{array}$} & \multirow{2}{*}{$\begin{array}{l}\text { GenBank } \\
\text { accession } \\
\text { No. }\end{array}$} & \multicolumn{2}{|l|}{ Closest identified relative } & \multirow{2}{*}{$\begin{array}{l}\text { Phylum of closest } \\
\text { relative }\end{array}$} & \multirow{2}{*}{$\begin{array}{l}\text { Source of isolation of } \\
\text { the closest relative }\end{array}$} & \multirow{2}{*}{$\begin{array}{l}\% \\
\text { Identity }\end{array}$} \\
\hline & & Species & $\begin{array}{l}\text { (GenBank } \\
\text { accession No.) }\end{array}$ & & & \\
\hline PKU F1 & KC113282 & Mucor sp. FJ09 & $(\mathrm{HQ019160)}$ & Zygomyceta & Water hyacinth leaf & 99 \\
\hline PKU F2 & KC113283 & Hypocrea koningii strain JZ-25 & (HQ637343) & Ascomycota & Soil from Sichuan & 99 \\
\hline PKU F3 & KC113284 & Arthrinium phaeospermum isolate T57 & (FJ462766) & Ascomycota & Not known & 99 \\
\hline PKU F4 & KC113285 & Diaporthe sp. H4236 & (GU595056) & Ascomycota & Mangrove in China & 98 \\
\hline PKU F5 & KC113286 & Phoma sp. ZH2.1 & (FJ450059) & Ascomycota & Argyrosomus argentatus & 99 \\
\hline PKU F6 & KC113287 & Trichoderma piluliferum strain wxm37 & (HM037939) & Ascomycota & River water & 99 \\
\hline PKU F7 & KC113288 & Trichoderma asperellum isolate T29 & (JN108927) & Ascomycota & Rhizospheric soil & 99 \\
\hline PKU F8 & KC113289 & Aspergillus nomius strain NRRL 26885 & (JF824686) & Ascomycota & Philanthus triangulum & 99 \\
\hline PKU F9 & KC113290 & Aspergillus flavipes isolate $\mathrm{BCT} 2-3$ & $(J Q 082507)$ & Ascomycota & Shark gills & 100 \\
\hline PKU F10 & KC113291 & Dothideomycetes sp. OY307 & $($ FJ571450 ) & Ascomycota & Not known & 99 \\
\hline PKU F11 & KC113292 & Arthrinium phaeospermum isolate DFFSCS004 & (JX156350) & Ascomycota & Deep-sea sediments & 99 \\
\hline PKU F12 & KC113293 & Hypocrea lixii isolate SZMC 20858 & $(J X 173851)$ & Ascomycota & Hungarian vegetables & 100 \\
\hline PKU F13 & KC113294 & Trichoderma hamatum strain LXM1 & (GQ220703 ) & Ascomycota & Saline-alkali soil & 100 \\
\hline PKU F14 & KC113295 & Cladosporium sp. JS1043 & (AM176680) & Ascomycota & Deep sea & 100 \\
\hline PKU F15 & KC113296 & Curvularia sp. B34 & $(\mathrm{HQ696021)}$ & Ascomycota & Moso Bamboo Seeds & 99 \\
\hline PKU F16 & KC113297 & Cladosporium sphaerospermum isolate IJL07 & ( EU823317) & Ascomycota & Soybean & 99 \\
\hline PKU F17 & KC113298 & Arthrinium sp. LH11 & $(\mathrm{HQ832842})$ & Ascomycota & Tea plants & 99 \\
\hline PKU F18 & KC113299 & Ascomycota sp. AR-2010 isolate TR063 & (HQ608095) & Ascomycota & Soil & 92 \\
\hline PKU F19 & KC113300 & Pleosporales sp. LH241 & (HQ832825) & Ascomycota & Tea plants & 100 \\
\hline PKU F20 & KC113301 & Cladosporium cladosporioides isolate 2728 & (EU272532) & Ascomycota & Plant & 99 \\
\hline PKU F21 & KC113302 & Pyrenochaeta sp. CF-2008 & (EU885415) & Ascomycota & Corneal ulcer & 99 \\
\hline PKU F22 & KC113303 & Aspergillus terreus strain 1B61 & (KF572455) & Ascomycota & Geothermal soil & 99 \\
\hline PKU Y1 & KC113304 & Rhodotorula mucilaginosa strain KDLYC24-1 & (HQ909092) & Basidiomycota & Not known & 99 \\
\hline PKU Y2 & KC113305 & Rhodotorula glutinis var. salinaria strain $\mathrm{ZH7}-(7)$ & (FJ487944) & Basidiomycota & Mangrove in China & 99 \\
\hline PKU Y3 & KC113306 & Aureobasidium pullulans strain KDLYC4-9 & (HQ909088) & Ascomycota & Not known & 99 \\
\hline PKU Y4 & KC113307 & Rhodosporidium sphaerocarpum isolate 2223 & (HQ670691) & Basidiomycota & Shrimp Culture & 99 \\
\hline PKU Y5 & KC113308 & Rhodosporidium diobovatum strain IWBT-Y840 & (JQ993385) & Basidiomycota & grapevines & 99 \\
\hline PKU Y6 & KC113309 & Trichosporon brassicae & (NR_073251) & Basidiomycota & Not known & 99 \\
\hline PKU Y7 & KC113310 & Rhodotorula mucilaginosa strain WC53-2 & (EF190221) & Basidiomycota & Not known & 99 \\
\hline PKU Y8 & KC113311 & Candida parapsilosis IFM52618 & (AB109284) & Ascomycota & Braziland Japan & 99 \\
\hline PKU Y9 & KC113312 & Rhodotorula mucilaginosa strain R-4685 & (KF726105) & Basidiomycota & Aortic valve & 100 \\
\hline
\end{tabular}


carboxymethylcellulose-sodium salt (CMC-Na), 1.0\% glucose, $0.15 \%$ peptone, $0.01 \%$ yeast extract, $100 \%$ seawater, and $2.0 \%$ agar. After growing the fungal isolates for 3 days at room temperature, these plates were stained with $0.1 \%$ Congo red solution for $20 \mathrm{~min}$ at room temperature. The resulting plates were washed twice with $1.0 \mathrm{M} \mathrm{NaCl}$, and were kept overnight at $4^{\circ} \mathrm{C}$. Clear zones around the colonies indicated the CMCase activities (Nagano and Fraser 2011; Carder et al. 1986). Lipase activity was detected using MEA plates supplemented with $0.01 \%$ phenol red, $1 \%$ olive oil and $10 \mathrm{mM} \mathrm{CaCl}_{2}$. The $\mathrm{pH}$ was adjusted to 7.3-7.4 with 1.0 M NaOH (Singh et al. 2006). After incubation for 3 days, a change in color from pink to yellow indicated the lipase activity.

\section{Quantitative analysis of enzymatic activities}

On the basis of qualitative screening, four fungal strains (PKU F16, PKU F18, PKU Y5 and PKU Y8) were selected for quantitative studies. Fungal inoculums were prepared by growing isolates in MEB medium and yeast in YPD medium, respectively, for four days at $28^{\circ} \mathrm{C}$. These inoculums were further subcultured to fresh MEB medium containing individual enzyme specific substrates and incubated on shaker at $30^{\circ} \mathrm{C}, 150 \mathrm{rpm}$ for 4 days. All these experiments were performed in triplicates. Individual enzymes were quantified in the supernatants of the isolates.

The laccase activity was assayed using glycine- $\mathrm{HCl}$ (pH3.0) buffer and ABTS as substrate (Niku-Paavola et al. 1988). Five hundred $\mu \mathrm{l}$ of crude culture filtrate was incubated with equal volumes of buffer containing ABTS and laccase activity was measured at $405 \mathrm{~nm}$. The enzyme units were expressed as $\mu \mathrm{M}$ of substrate transformed per minute per liter of culture filtrate i.e. as enzyme units per liter of culture filtrate $\left(\mathrm{UL}^{-1}\right)$. In the absence of the enzyme activity, no increase in the rate of absorbance was observed.

Cellulase activity was assayed following the method described by Raghukumar et al. (1994). A reaction mixture containing $200 \mu \mathrm{l}$ culture filtrate and $200 \mu \mathrm{l}$ of $0.5 \%$ $\mathrm{CMC}$ in $0.05 \mathrm{M}$ sodium phosphate buffer, $\mathrm{pH} 7$ was incubated at $37^{\circ} \mathrm{C}$ for $30 \mathrm{~min}$. To terminate the reaction, $1 \mathrm{ml}$ of DNS (dinitrosalicylic acid) reagent was added to above reaction mixture and then was boiled for $5 \mathrm{~min}$. CMCase activity was measured at $575 \mathrm{~nm}$. One unit of CMCase activity was defined as the amount of enzyme liberating $1 \mu \mathrm{M}$ of reducing sugar per minute under the above assay conditions.

For lipase assay, $6 \mathrm{mg}$ para-nitrophenyl palmitate (pNPP), dissolved in $2 \mathrm{ml}$ isopropanol and $18 \mathrm{ml} 50 \mathrm{mM}$ sodium phosphate buffer $(\mathrm{pH}$ 8) was used as the substrate. One $\mathrm{ml}$ each of culture filtrate and sodium phosphate buffer was added to $1 \mathrm{ml}$ of the pNPP substrate solution. After incubating at $37^{\circ} \mathrm{C}$ for $30 \mathrm{~min}$, the released product, pNP (para-nitrophenol) was measured at $410 \mathrm{~nm}$. One unit of lipase activity was defined as the amount of enzyme liberating $1 \mu \mathrm{M}$ of pNP per minute under these assay conditions.

\section{Fungal pelletization experiment}

Three of the fungal isolates (Mucor sp., PKU F1), (Aspergillus sp., PKU F8) and (Cladosporium sp., PKU F14) were investigated for pellet formation in this study. The spore suspension from these species was obtained by rinsing the mycelia on media plate with distilled water containing $10 \%$ Tween 20 . The number of spores in the suspension was counted using an optical microscope (Olympus BX53 Manual fluorescence microscope). The spore suspensions were added to the 250-mL Erlenmeyer flasks containing $50 \mathrm{ml}$ of nutrient media (Malt Extract Broth). The pellet formation experiments were performed by placing these Erlenmeyer flasks on a horizontal shaker $(100 \mathrm{rpm})$ at room temperature for 4 days. The pellet formation was analyzed at different spore concentrations and $\mathrm{pH}$ ranges (2-8).

\section{Results}

\section{Culturable diversity}

Fungi were isolated from all the seawater depths in the present study (Table 1). However, maximum numbers of fungal colonies were recovered from surface sediments (0 $\mathrm{m}$ depth) and seawater samples at $10 \mathrm{~m}$ depth. Fungi were also recovered from sediment samples using particle plating technique (Table 1). SDA was found to be better media than MEA for the isolation of fungi (Table 1). However, there was no statistical significance observed between different depths, media and the number of fungal colonies. A total of 22 fungi and 9 yeasts were isolated in this study. The fungal isolates mostly belonged to Ascomycota, Basidiomycota and Zygomycota based on ITS rRNA gene analysis (Table 2, Figure 1). Fungal isolates showing similarity with the phylum

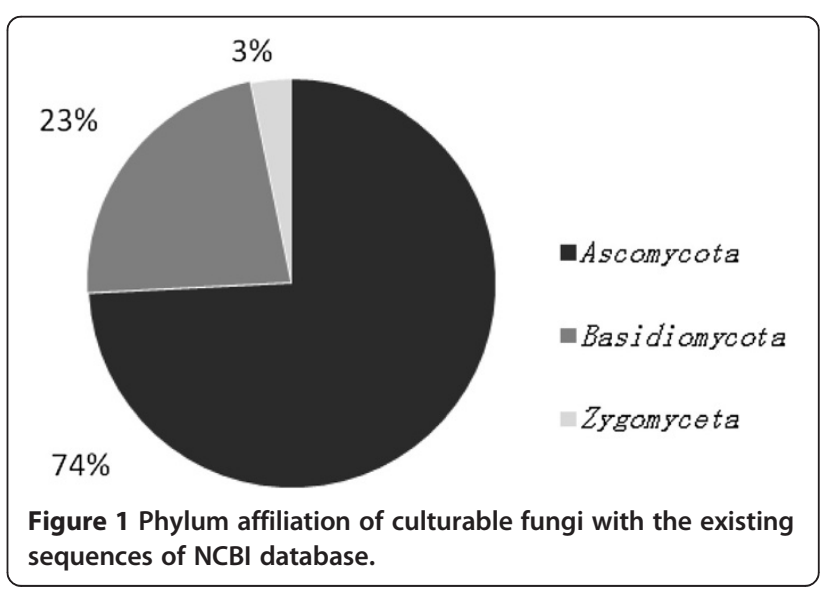




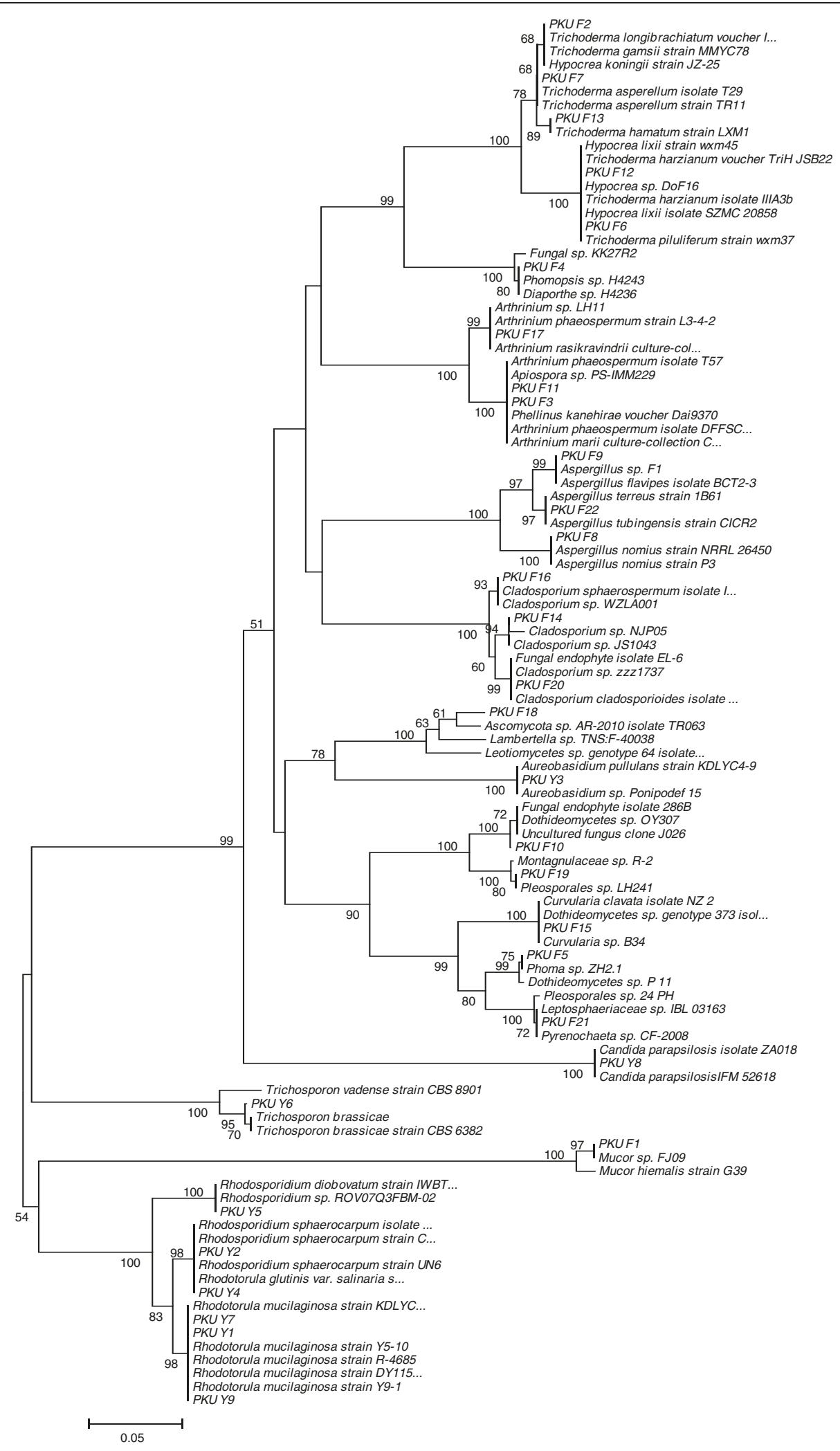

Figure $2 \mathrm{NJ}$ phylogenetic tree based on ITS rRNA genes from 22 fungi and 9 yeast derived from coastal ecosystems of Pearl River Delta. Numbers at nodes indicate bootstrap values of neighborjoining analysis for 1,000 replicates (values below $50 \%$ not shown). 
Ascomycota were dominating among above three, accounting for 74\%. Members of Basidiomycota and Zygomycota made up for $23 \%$ and $3 \%$, respectively (Figure 1 ). Of the Ascomycetes, isolates belonged to 13 genera i.e. Aspergillus, Hypocraea, Arthrinium, Diaporthe, Phoma, Trichoderma, Dothideomycetes, Cladosporium, Curvularia, Pleosporales, Pyrenochaeta, Aureobasidium and Candida. Isolates of Basidiomycota were affiliated with Rhodotorula, Rhodosporidium and Trichosporon sp. Only Mucor sp. of Zygomycota was identifed in this study (Table 2, Figure 2). All the fungal ITS rRNA gene sequences showed 100 or 99\% identity with the existing sequences of NCBI database except PKU F18, showing 92\% identity with Ascomycota sp. AR-2010 (Table 2).

\section{Enzymatic activities}

Qualitative analyses of different enzymes demonstrated positive result for most of the fungal isolates (Table 3, Figure 3$)$. The majority of fungal isolates $(\sim 84 \%)$ exhibited cellulase and lipase activities. In comparison, only a few of the isolates $(\sim 38 \%)$ showed positive laccase activity (Table 3, Figure 3). The quantitative analyses for production of these three enzymes were done for four of these fungal isolates (Table 4). Cladosporium sp. (PKU F16), Rhodosporidium sp. (PKU Y5) and Candida sp. (PKU Y8) showed considerable production of lipase enzyme, reaching up to $21.94 \mathrm{U} \mathrm{ml}^{-1}$ for Candida sp. In contrast, cellulase production was not very high for any of these isolates, being maximum of $1.3 \mathrm{U} \mathrm{ml}^{-1}$

Table 3 Qualitative assay of enzyme activities on media plates amended with specific substrates

\begin{tabular}{|c|c|c|c|c|c|}
\hline Isolate ID & Laccase $\left(4^{\text {th }}\right.$ day $)$ & Lipase ( $3^{\text {rd }}$ day) & Cellulase ( $3^{\text {rd }}$ day) & Source of isolation & Depth (m) \\
\hline PKU F1 & - & + & + & Seawater & 0 \\
\hline PKU F2 & + & - & + & Seawater & 0 \\
\hline PKU F3 & + & ++ & ++ & Seawater & 0 \\
\hline PKU F4 & ++ & + & + & Seawater & 0 \\
\hline PKU F5 & - & ++ & - & Sediment & 0 \\
\hline PKU F6 & - & - & + & Seawater & 0 \\
\hline PKU F7 & ++ & + & ++ & Sediment & 0 \\
\hline PKU F8 & - & + & ++ & Sediment & 0 \\
\hline PKU F9 & - & ++ & ++ & Sediment & 0 \\
\hline PKU F10 & + & - & - & Sediment & 0 \\
\hline PKU F11 & + & ++ & +++ & Seawater & 10 \\
\hline PKU F12 & - & ++ & ++ & Seawater & 10 \\
\hline PKU F13 & - & ++ & +++ & Seawater & 0 \\
\hline PKU F14 & ++ & +++ & ++ & Seawater & 0 \\
\hline PKU F15 & + & - & - & Seawater & 10 \\
\hline PKU F16 & +++ & +++ & ++ & Seawater & 5 \\
\hline PKU F17 & - & ++ & + & Seawater & 10 \\
\hline PKU F18 & +++ & + & +++ & Seawater & 0 \\
\hline PKU F19 & - & + & - & Seawater & 0 \\
\hline PKU F20 & ++ & ++ & ++ & Seawater & 0 \\
\hline PKU F21 & + & ++ & - & Seawater & 0 \\
\hline PKU F22 & - & +++ & ++ & Seawater & 0 \\
\hline PKU Y1 & - & ++ & + & Seawater & 0 \\
\hline PKU Y2 & - & + & ++ & Seawater & 0 \\
\hline PKU Y3 & - & ++ & + & Seawater & 10 \\
\hline PKU Y4 & - & + & ++ & Seawater & 0 \\
\hline PKU Y5 & - & ++ & ++ & Seawater & 10 \\
\hline PKU Y6 & - & ++ & ++ & Seawater & 5 \\
\hline PKU Y7 & - & - & ++ & Seawater & 0 \\
\hline PKU Y8 & - & +++ & +++ & Seawater & 0 \\
\hline PKU Y9 & - & ++ & ++ & Seawater & 10 \\
\hline
\end{tabular}




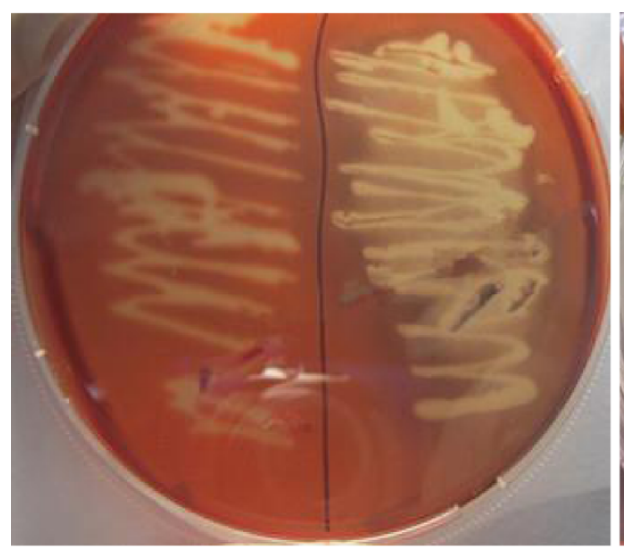

A

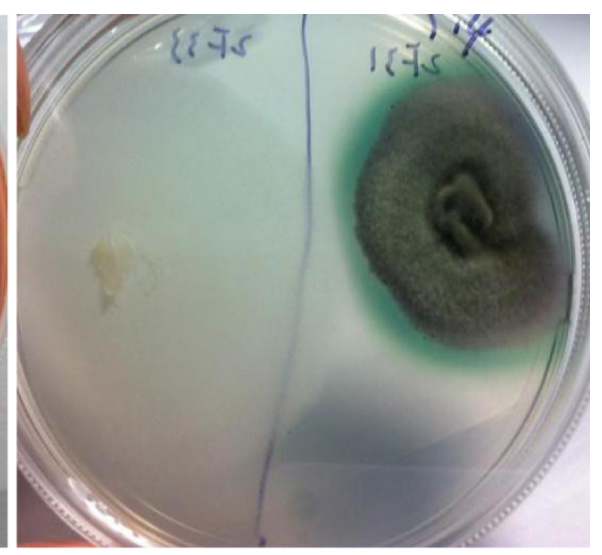

B

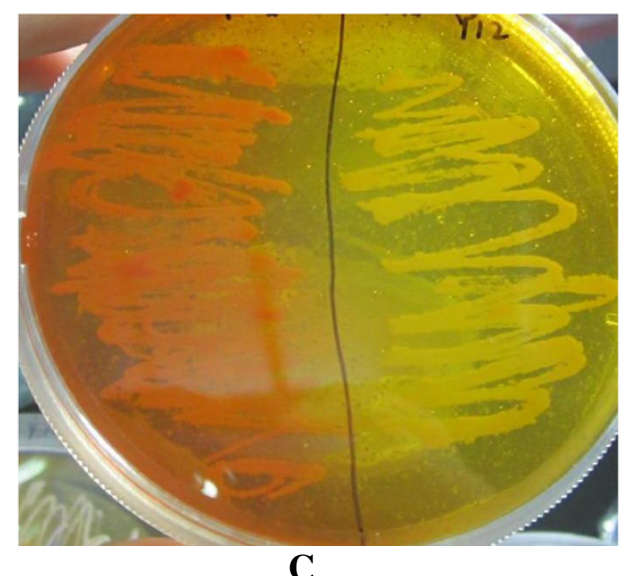

Figure 3 Qualitative assay of enzyme activities of fungi on substrate specific media plates. A. Plate assay for cellulose activities (PKU Y7 Rhodotorula mucilaginosa sp. (left) and PKU Y9 Rhodotorula mucilaginosa sp. showing good cellulose activity (rght)); B. Plate assay for laccase activities (PKU F11 Arthrinium phaeospermum sp. showing no laccase activity (left); PKU F16 Cladosporium sphaerospermum showing considerable laccase activities (right)); C. Plate assay for lipase activities on plate (PKU Y7 Rhodotorula mucilaginosa sp. showing little lipase activity (left); PKU Y9 Rhodotorula mucilaginosa sp. showing good lipase activity (right)).

demonstrated by Candida sp. PKU F16 (Cladosporium sp.) and PKU F18 (Ascomycota sp.) were the best producers of laccase enzyme showing activities of $14.6 \mathrm{U} \mathrm{ml}$ ${ }^{-1}$ and $10.5 \mathrm{U} \mathrm{ml}^{-1}$ respectively (Table 4). All the isolates showed maximum production of these extracellular enzymes on $6^{\text {th }}$ day of their growth (Table 4).

\section{Fungal pellet formation}

Among three fungal isolates i.e. Aspergillus sp. (PKU F8), Mucor (PKU F1) and Cladosporium sp. (PKU F14), PKU F1 was found to be the best agent for pellet formation (Table 5, Additional file 1: Figure S2). The $\mathrm{pH}$ range of 6 and 8 were most suitable for all of these four isolates for pellet formation. Pellet sizes were comparative bigger with higher concentration of spore inoculums for Mucor sp. (Table 5). However, Aspergillus sp. did not show much variation with inoculum spore concentrations (Table 5). Maximum size of pellet of $7 \mathrm{~mm}$ was demonstrated by Aspergillus sp. (PKU F8) at $\mathrm{pH} 8$.

\section{Discussion}

Diversity of fungi has been reported from various environments such as freshwater (Gulis et al. 2006), marine environments such as coastal waters (Gao et al. 2010), deep-sea sediments (Damare et al. 2006; Singh et al. 2010), hypersaline waters (Buchalo et al. 2000), methane hydrates (Lai et al. 2007), oxygen deficient ecosystems (Cathrine and Raghukumar 2009), mangroves and salt marshes (Hyde et al. 1998; Raghukumar 2004), and hydrothermal vents (Le Calvez et al. 2009). This study is the first report on culturable diversity of fungi from coastal ecosystems of Pearl River Delta, China.

Despite of being isolated from coastal environment, the diversity of fungi was observed to be comparatively less, resulting into a total of 22 filamentous fungi and 9 yeast isolates. The isolated fungi belonged mostly to $A s-$ comycota, Basidiomycota and at a very less percentage of Zygomycota (Table 2). Previous studies have also reported abundance of above fungal phylotypes in coastal 
Table 4 Quantitative assay of enzyme activities for four fungal isolates

\begin{tabular}{|c|c|c|c|c|c|}
\hline Isolate ID & Fungal genera & Growthdate & Lipase $\left(\mathrm{Umin}^{-1} \mathrm{ml}^{-1}\right)$ & Cellulase $\left(\mathrm{Umin}^{-1} \mathrm{ml}^{-1}\right)$ & Laccase $\left(\mathrm{Umin}^{-1} \mathrm{ml}^{-1}\right)$ \\
\hline \multirow[t]{2}{*}{ PKU F16 } & Cladosporium sp. & 6th day & $14.384 \pm 0.994$ & $0.843 \pm 0.084$ & $10.495 \pm 1.300$ \\
\hline & & 9th day & $12.285 \pm 0.772$ & $0.443 \pm 0.032$ & $5.105 \pm 0.943$ \\
\hline \multirow[t]{2}{*}{ PKU F18 } & Ascomycota sp. & 6th day & $6.605 \pm 0.959$ & $1.133 \pm 0.096$ & $14.609 \pm 1.039$ \\
\hline & & 9th day & $4.630 \pm 0.812$ & $1.001 \pm 0.049$ & $7.581 \pm 1.642$ \\
\hline \multirow[t]{2}{*}{ PKU Y5 } & Rhodosporidium sp. & 6th day & $17.174 \pm 0.742$ & $0.333 \pm 0.040$ & - \\
\hline & & 9th day & $12.186 \pm 1.705$ & $0.371 \pm 0.028$ & - \\
\hline \multirow[t]{2}{*}{ PKU Y8 } & Candida sp. & 6th day & $21.940 \pm 1.582$ & $1.311 \pm 0.013$ & - \\
\hline & & 9th day & $18.767 \pm 1.554$ & $1.132 \pm 0.029$ & - \\
\hline
\end{tabular}

seawater ecosystems (Gao et al. 2010). The results obtained in the present study are also in concordance with earlier reports where surface water of coastal ecosystems has been reported to contain higher mycoplankton diversity compared with open-ocean ecosystems (Gao et al. 2010). However, use of only culture-dependent approach in this study for estimation of diversity may have limited the isolation of other genera of fungi which are present as uncultivable forms in the oceanic habitats. Previous studies have reported a greater percentage of fungal diversity when assayed using combined approach of culture-dependent and culture-independent methods (Singh et al. 2012). Therefore, a detailed study on fungal diversity from Pearl River Delta using both the approaches may provide a greater insight on hidden, still unexplored mycoplankton communities in future. The diversity of fungi has also been reported to vary with the nutrient contents of any particular habitat, which can be available as detritus for the fungal population (Newell 1982).

Isolation of fungi was attempted using five different media (MEA, SDA, CMA, PDA and CMA). However, fungal isolates were recovered only on two media i.e., MEA and SDA (Table 3). In contrast, the fungal isolates were obtained with all the above five media during isolation from deep-sea sediments by Singh et al. (2012). Most of the isolates affiliated with the existing sequences of NCBI data base at the percentage identity of 100 or 99 . However, the $92 \%$ identity of the fungal sequence PKU F18 with Ascomycota sp., suggests its probability of being novel. On the contrary, the insufficient database for ITS sequences may also be one of the reasons for such low similarity values (Zachow et al. 2009; Anderson et al. 2003).

The production of extracellular enzymes i.e., laccase. cellulase and lipase was demonstrated by most of the fungal isolates in the present study, suggesting their active role in various ecological cycles of coastal ecosystems off China. Laccase in one of the important lignin degrading enzymes, demonstrated to decolorize a range of dyes and toxic industrial effluent in earlier reports (Nyanhongo et al. 2002). The fungal isolates PKU F16 and PKU F18, showing considerable quantitative production of laccase in the present study render them possible candidates for industrial application (Table 4). Cellulose is the most common substrate present in the seawater column in the form of plant biomass. It is found in nature exclusively in plant cell walls, although it is produced by some animals also e.g., tunicates and few bacteria (Lynd et al. 2002). Fungi are well known agents of decomposition of organic matter composed of cellulosic substrate in particular (Lynd et al. 2002). Therefore, cellulase production by the fungal isolates in the present study suggest their active involvement in the mineralization and leaf litter degradation in the coastal sea water habitats. Lipases are ubiquitous enzymes of considerable

Table 5 Details regarding pellet formation by the fungal isolates

\begin{tabular}{|c|c|c|c|c|c|c|c|}
\hline \multirow{3}{*}{$\begin{array}{l}\text { Isolate } \\
\text { ID }\end{array}$} & \multirow[t]{3}{*}{ Species } & \multirow{3}{*}{$\begin{array}{l}\text { No. of } \\
\text { spores } \\
\text { (per L) }\end{array}$} & \multirow{3}{*}{$\begin{array}{l}\text { Pellet } \\
\text { color }\end{array}$} & \multicolumn{4}{|l|}{ Different $\mathrm{pH}$} \\
\hline & & & & $\mathrm{PH}=2$ & $\mathrm{PH}=4$ & $\mathrm{PH}=6$ & $\mathrm{PH}=8$ \\
\hline & & & & Pellet size $(\mathrm{mm})$ & Pellet size $(\mathrm{mm})$ & Pellet size $(\mathrm{mm})$ & Pellet size $(\mathrm{mm})$ \\
\hline \multirow[t]{2}{*}{ PKU F1 } & Mucor sp. FJ09 & $4.00 * 10^{6}$ & yellow & - & cotton- shaped & 5 & 4 \\
\hline & & $1.60^{*} 10^{7}$ & yellow & - & cotton- shaped & 2 pellets $\left(20^{*} 10\right) /\left(5^{*} 10\right)$ & 1 pellet $\left(20^{*} 10\right)$ \\
\hline \multirow[t]{2}{*}{ PKU F8 } & Aspergillus nomius strain & $1.59^{*} 10^{7}$ & white & $<0.5$ & $4-6$ & 3 & $3-7$ \\
\hline & & $6.34^{*} 10^{7}$ & white & $<0.5$ & $1-2$ & 3 & 4 \\
\hline \multirow[t]{2}{*}{ PKU F14 } & Cladosporium sp. & $3.85 * 10^{8}$ & black & $<0.1$ & 0.5 & $0.5-1$ & $1-2$ \\
\hline & & $1.54^{*} 10^{9}$ & black & - & - & - & 1 \\
\hline
\end{tabular}


industrial and physiological significance. They catalyze the hydrolysis of triacylglycerols to glycerol and free fatty acids. Lipases are widely used in the processing of fats and oils, detergents and degreasing formulations, food processing, the synthesis of fine chemicals and pharmaceuticals, paper manufacture, and production of cosmetics, and pharmaceuticals (Rubin and Dennis 1997a, b; Kazlauskas and Bornscheuer 1998). Lipase production up to $21.9 \mathrm{U} \mathrm{ml}^{-1}$ by Candida sp. in the present study reveals the potential of this fungus towards lipolytic degradation abilities. Additionally, the optimization of media and nutrient condition for enhanced lipase production from above isolate may be applied in future to maximize their industrial application and commercialization.

Fungi have been characterized widely for their efficient role in pellet formation towards harvesting of algae and wastewater treatment (Zhou et al. 2012). The microalgae cells can be processed into a broad spectrum of biofuels by the transesterification process. These biofuels include biodiesel, green diesel and gasoline, being produced by transformation of algal biomass using various technologies (Chisti 2007). However, many challenges have restricted the development of algal biofuel technology to commercial practicality that could allow for sustainable production and utilization (Brennan and Owende 2010). Among these, one is the harvesting process of algae, which can be improved by application of agents, causing aggregation of algal cells. The pellet formation capabilities exhibited by three of the fungal isolates in the present study (Table 5, Additional file 1: Figure S2) opens new avenues for their efficient utilization towards algae harvesting and wastewater treatment. In addition, the pellet formation capabilities of fungi have been shown to be affected widely by various factors such as $\mathrm{pH}$, inoculum concentration and trace metals (Zhou et al. 2000). A co-cultivation method using fungi of the present study with algal strains under different $\mathrm{pH}$, trace metals and inoculum concentration for efficient optimization of the harvesting process is suggested for future studies.

In conclusion, the fungal diversity obtained from this study was low. The fungal isolates belonged to three major phyla i.e., Ascomycota, Basidiomycota and Zygomycota, with Ascomycota being the dominant forms. The different qualitative as well as quantitative levels of extracellular enzymes produced by these isolates suggests them as significant component of the ecological cycles of coastal ecosystems off Pearl River Delta. Finally, the production of enzymes and pellet formation abilities of a few fungal isolates indicate their possible utilization in biotechnological industries.

\section{Additional file}

Additional file 1: Figure S1. Microscopic photograph of fungal isolates. Figure S2. Pellet formation by different fungal isolates using spores as inoculums at $\mathrm{PH} 6$.

\section{Competing interests}

The authors declare that they have no competing interests.

\section{Author's contributions}

GW \& PS conceived and designed the experiments; LL \& YL performed the experiments; PS \& LL analyzed the data; GW \& PS contributed reagents/ materials/analysis tools; PS, LL, GW \& SQP wrote the paper. All authors read and approved the final manuscript.

\section{Acknowledgements}

This work was partially funded by National Science Foundation of China grant 31170109 (GYW) and Shenzhen Development and Reform Commission grant 835 (GYW)

\section{Author details}

${ }^{1}$ School of Environment and Energy, Peking University Shenzhen Graduate School, Shenzhen, 518055, China. ${ }^{2}$ Department of Biological Science, National University of Singapore, Singapore 117543, Singapore. ${ }^{3}$ Tianjin University Center for Marine Environmental Ecology, School of Environmental Science and Engineering, Tianjin University, Tianjin 300072, China.

${ }^{4}$ Department of Microbiology, University of Hawaii at Manoa, Honolulu, HI 96822, USA.

Received: 17 May 2014 Accepted: 9 July 2014

Published online: 30 August 2014

\section{References}

Altschul SF, Gish W, Miller W, Myers EW, Lipman DJ (1990) Basic local alignment search tool. J Mol Biol 215:403-410

Anderson IC, Campbell CD, Prosser JI (2003) Potential bias of fungal $18 \mathrm{~S}$ rDNA and internal transcribed spacer polymerase chain reaction primers for estimating fungal biodiversity in soil. Environ Microbiol 5:36-47

Brennan L, Owende P (2010) Biofuels from microalgae-a review of technologies for production, processing, and extractions of biofuels and co-products. Renew Sustain Energy Rev 14:557-577

Buchalo AS, Nevo E, Wasser SP, Volz PA (2000) Newly discovered halophilic fungi in the Dead Sea (Israel). In: Seckbach J (ed) Journey to diverse microbial worlds. Kluwer, Dordrecht, The Netherlands, pp 239-252

Bungihan ME, Tan MA, Kitajima M, Kogure N, Franzblau SG, Cruz TEE, Takayama H, Nonato MG (2011) Bioactive metabolites of Diaporthe sp. P133, an endophytic fungus isolated from Pandanus amaryllifolius. J Nat Med 65:606-609

Carder KL, Steward RG, Paul JH, Vargo GA (1986) Relationships between chlorophyll and ocean color constituents as they affect remote-sensing reflectance models. Limnol Oceanogr 31:403-413

Cathrine SJ, Raghukumar C (2009) Anaerobic denitrification in fungi from the coastal marine sediments off Goa, India. Mycol Res 11:100-109

Chi Z, Wang F, Chi Z, Yue L, Liu G, Zhang T (2009) Bioproducts from Aureobasidium pullulans, a biotechnologically important yeast. Appl Microbiol Biotechnol 82:793-804

Chisti Y (2007) Biodiesel from microalgae. Biotechnol Adv 25:294-306

Christensen M (1989) A view of fungal ecology. Mycol 81:1-19

Damare V, Raghukumar S (2008) Abundance of thraustochytrids and bacteria in the equatorial Indian Ocean, in relation to transparent exopolymeric particles (TEPS). FEMS Microbiol Ecol 65:40-49

Damare S, Raghukumar C, Raghukumar S (2006) Fungi in deep-sea sediments of the Central Indian Basin. Deep-Sea Res Part I 53:14-27

Danovaro R, Pusceddu A (2007) Biodiversity and ecosystem functioning in coastal lagoons: does microbial diversity play any role? Estuar Coast Shelf Sci 75:4-12

Fenchel T (2008) The microbial loop-25 years later. J Exp Mar Biol Ecol 366:99-103

Gao Z, Johnson ZI, Wang G (2010) Molecular characterization of the spatial diversity and novel lineages of mycoplankton in Hawaiian coastal waters. ISME J 4:111-120 
Giovannoni SJ, Stingl U (2005) Molecular diversity and ecology of microbial plankton. Nature 437:343-348

Gulis V, Kuehn K, Suberkropp K (2006) The role of fungi in carbon and nitrogen cycles in freshwater ecosystems. In: Gadd GM (ed) Fungi in biogeochemical cycles. Cambridge University Press, New York, pp 405-435

Gutiérrez MH, Pantoja S, Quiňones RA, González RR (2010) First record of filamentous fungi in the coastal upwelling ecosystem off central Chile. Gayana 74:66-73

Gutiérrez MH, Pantoja S, Tejos E, Quiňones RA (2011) Role of fungi in processing marine organic matter in the upwelling ecosystem off Chile. Mar Biol 158:205-219

Hallam SJ, Mincer TJ, Schleper C, Preston CM, Roberts K, Richardson PM, DeLong EF (2006) Pathways of carbon assimilation and ammonia oxidation suggested by environmental genomic analyses of marine Crenarchaeota. PLOS Biol 4:520-536

Hyde KD, Jones EBG, Leano E, Pointing SB, Poonyth AD, Vrijmoed LLP (1998) Role of fungi in marine ecosystems. Biodivers Conserv 7:1147-1161

Jickells TD (1998) Nutrient biogeochemistry of the coastal zone. Science 281:217-222

Kaul S, Gupta S, Ahmed M, Dhar MK (2013) Endophytic fungi from medicinal plants: a treasure hunt for bioactive metabolites. Phytochem Rev 11:487-505

Kazlauskas RJ, Bornscheuer UT (1998) Biotransformations with lipases. In: Rehm HJ, Pihler G, Stadler A, Kelly PJW (eds) Biotechnology, vol 8. VCH, New York, pp 37-192

Kiørboe T, Jackson GA (2001) Marine snow, organic solute plumes, and optimal sensory behaviour of bacteria. Limnol Oceanogr 46:1309-1318

Lai X, Cao L, Tan H, Fang S, Huang Y, Zhou S (2007) Fungal communities from methane hydrate-bearing deep-sea marine sediments in South China Sea. ISME J 1:756-762

Le Calvez T, Burgaud G, Mahe S, Barbier G, Vandenkoornhuyse P (2009) Fungal diversity in deep-sea hydrothermal ecosystems. Appl Environ Microbiol 75:6415-6421

Lynd LR, Weimer PJ, Van ZyI WH, Pretorius IS (2002) Microbial cellulose utilization: fundamentals and biotechnology. Microbiol Mol Biol Rev 66:506-577

Manini E, Fiordelmondo C, Gambi C, Pusceddu A, Danovaro R (2003) Benthic microbial loop functioning in coastal lagoons: a comparative approach. Oceanolog Acta 26:27-38

Moran MA, Miller WL (2007) Resourceful heterotrophs make the most of light in the coastal ocean. Na Rev Microbiol 5:792-800

Mou XZ, Sun SL, Edwards RA, Hodson RE, Moran MA (2008) Bacterial carbon processing by generalist species in the coastal ocean. Nature 451:708-711

Nagano T, Fraser P (2011) No-nonsense functions for long noncoding RNAs. Cell 145:178-181

Newell RC (1982) The energetics of detritus utilisation in coastal lagoons and nearshore waters. In: Laserre P, Postma H (eds) Proceedings of International Symposium on Coastal Lagoos; 8-14 September 1981; Oceanologica Acta (Special issue). SCOR/IABO/UNESCO, Bordeaux, pp 347-355

Newell SY (1994) Ecomethodology for organo-osmotrophs, prokaryotic unicellular versus eukaryotic mycelial. Microb Ecol 28:151-157

Niku-Paavola ML, Karhunen E, Salola P, Raunio V (1988) Lignolytic enzymes of the white-rot fungus Phlebia radiata. Biochem J 254:877-884

Nyanhongo GS, Gomes J, Gübitz GM, Zvauya R, Read J, Steiner W (2002) Decolorization of textile dyes by laccases from a newly isolated strain of Trametes modesta. Wat Res 36:1449-1456

Pang KL, Mitchell J (2005) Molecular approaches for assessing fungal diversity in marine substrata. Bot Mar 48:332-347

Pusceddu A, Dell'Anno A, Danovaro R, Manini E, Sara G, Fabiano M (2003) Enzymatically hydrolysable protein and carbohydrate sedimentary pools as indicators of the trophic state of detritus sink systems: a case study in a Mediterranean coastal lagoon. Estuar 26:641-650

Raghukumar S (2004) The role of fungi in marine detrital processes. In: Ramaiah $N$ (ed) Marine Microbiology: Facets \& Opportunities. National Institute of Oceanography, Goa, India, pp 91-101

Raghukumar S, Sharma S, Raghukumar C, Sathe-Pathak V, Chandramohan D (1994) Thraustochytrid and fungal component of marine detritus. IV. Laboratory studies on decomposition of leaves of the mangrove Rhizophora apiculata Blume. J Exp Mar Biol Ecol 183(1):113-131

Richards TA, Jones MD, Leonard G, Bass D (2012) Marine fungi: their ecology and molecular diversity. Ann Rev Mar Sci 4:495-522

Rubin B, Dennis EA (1997a) Lipases: Part A. Biotechnology Methods in enzymology, vol 284. Academic Press, New York, pp 1-408
Rubin B, Dennis EA (1997b) Lipases: Part B. Enzyme characterization and utilizationMethods in enzymology, vol 286. Academic Press, New York, pp 1-563

Singh R, Gupta N, Goswami VK, Gupta R (2006) A simple activity staining protocol for lipases and esterases. Appl Microbiol Biot 70:679-682

Singh P, Raghukumar C, Verma P, Shouche Y (2010) Phylogenetic diversity of culturable fungi from the deep-sea sediments of the Central Indian Basin and their growth characteristics. Fungal Divers 40:89-102

Singh P, Raghukumar C, Verma P, Shouche Y (2012) Fungal diversity in deep-sea sediments revealed by culture-dependent and culture-independent approaches. Fungal Ecol 5:543-553

Srinivasan C, Dsouza TM, Boominathan K, Reddy CA (1995) Demonstration of laccase in the white rot basidiomycete phanerochaete chrysosporium BKM-F1767. Appl Environ Microbiol 61:4274-4277

Strom SL (2008) Microbial ecology of ocean biogeochemistry: A community perspective. Science 320:1043-1045

Tamura K, Dudley J, Nei M, Kumar S (2007) MEGA4: molecular evolutionary genetics analysis (MEGA) software version 4.0. Mol Biol Evol 24:1596-1599

Thompson JD, Higgins DG, Gibson TJ (1994) CLUSTAL W: improving the sensitivity of progressive multiple sequence alignment through sequence weighting, position-specific gap penalties and weight matrix choice. Nucleic Acids Res 22:4673-4680

Tisdall JM, Oades JM (1982) Organic matter and water-stable aggregates in grassland soils. J Soil Sci 33:141-163

Wang GY, Johnson ZI (2009) Impact of parasitic fungi on the diversity and functional ecocology of marine phytoplankton. In: Kersey TW, Munger SP (eds) Marine Phytoplankton. Nova Science Publishers, Hauppauge, NY pp 211-228

White TJ, Bruns T, Lee S (1990) Amplification and direct sequencing of fungal ribosomal RNA genes for phylogenetics. PCR Protocols: a Guide to Methods and Applications 18:315-322

Zachow C, Berg C, Muller H, Meincke R, Komon-Zelazowska M, Druzhinina IS, Kubicek CP, Berg G (2009) Fungal diversity in the rhizosphere of endemic plant species of Tenerife (Canary Islands): relationship to vegetation zones and environmental factors. ISME J 3:79-92

Zhou Y, Du J, Tsao GT (2000) Mycelial Pellet Formation by Rhizopus oryzae ATCC 20344. Appl Biochem Biotechnol 84:779-789

Zhou WG, Cheng YL, Li Y, Wan YQ, Liu YH, Lin XY, Ruan R (2012) Novel fungal pelletization assisted technology for algae harvesting and wastewater treatment. Appl Biochem Biotechnol 167:214-228

\section{doi:10.1186/s13568-014-0060-9}

Cite this article as: Li et al.: Diversity and biochemical features of culturable fungi from the coastal waters of Southern China. AMB Express 2014 4:60.

\section{Submit your manuscript to a SpringerOpen ${ }^{\circ}$ journal and benefit from:}

- Convenient online submission

$\checkmark$ Rigorous peer review

- Immediate publication on acceptance

- Open access: articles freely available online

- High visibility within the field

- Retaining the copyright to your article

Submit your next manuscript at springeropen.com 